Authors' contribution/

Wkład autorów:

A. Zaplanowanie badań/

Study design

B. Zebranie danych/

Data collection

C. Analiza statystyczna/

Statistical analysis

D. Interpretacja danych/

Data interpretation

E. Przygotowanie tekstu/

Manuscript preparation

F. Opracowanie

piśmiennictwa/

Literature search

G. Pozyskanie funduszy/

Funds collection
ECONOMIC AND REGIONAL STUDIES

STUDIA EKONOMICZNE I REGIONALNE

ISSN 2083-3725

Volume 10, No. 4, 2017

\section{REVIEW OF THE BOOK “SIECI WSPÓŁPRACY TRANSGRANICZNEJ NA POGRANICZACH POLSKI" BY SYLWIA DOŁZBŁASZ, WYDAWNICTWO UNIWERSYTETU WROCŁAWSKIEGO, WROCŁAW 2017, 290 PP.}

\author{
RECENZJA KSIĄŻKI SYLWII DOŁZBŁASZ PT. „SIECI WSPÓŁPRACY \\ TRASNGRANICZNEJ NA POGRANICZACH POLSKI", WYDAWNICTWO \\ UNIWERSYTETU WROCŁAWSKIEGO, WROCŁAW 2017, S. 290
}

\author{
Dawid Błaszczak
}

Pope John Paul II State School of Higher Education in Biała Podlaska Państwowa Szkoła Wyższa im. Papieża Jana Pawła II w Białej Podlaskiej

Błaszczak D. (2017), Review of the book „Sieci wspótpracy transgranicznej na pograniczach Polski” by Sylwia Dołzbłasz, Wydawnictwo Uniwersytetu Wrocławskiego, Wrocław 2017, 290 pp./ Recenzja książki Sylwii Dołzbłasz pt. „Sieci współpracy trasngranicznej na pograniczach Polski”, Wydawnictwo Uniwersytetu Wrocławskiego, Wrocław 2017, s. 290. Economic and Regional Studies, Vol. 10, No. 4, pp. 120-123. https://doi.org/10.29316/ers-seir.2017.40
The structuring and development of network structures is considered by many authors to be the dominant feature of social processes and phenomena of the 21st century (Barney 2008, Bendyk 2004, Castells 2007, 2009, 2013). Networks with increasing dynamics encompass various spheres and levels of social reality, both on a micro- and macro-social scale. "They form a basic pattern of every life" (Castells 2013, p. 33). As a consequence, networks of connections are also becoming an important element in shaping cross-border cooperation, and thus, a key subject of scientific research. An example of the application of the network perspective on the research on borders and borderlands is the scientific monograph "Sieci współpracy transgranicznej na pograniczach Polski", whose author is dr. Sylwia Dołzbłasz, an employee of the Institute of Geography and Regional Development of the University of Wrocław.

The book is a rich theoretical-empirical study, whose subject of research is "(...) identification of the most important features of cross-border cooperation at the local level in terms of network and analysis of the diversity of cooperation in Poland (...)" (Dołzbłasz 2017, p. 11). For the research, the author analysed bilateral activities under crossborder cooperation programs co-financed from the EU funds and implemented in the border areas of Poland. The starting point for the network analysis was determining the subject area of cooperation and the degree of individual institutions' involvement in cooperation. Determining and visualizing its
Kształtowanie i rozwój struktur sieciowych przez wielu autorów uznawane jest za dominantę procesów i zjawisk społecznych XXI wieku (Barney 2008; Bendyk 2004; Castells 2007, 2009, 2013). Sieci z coraz większą dynamiką oplatają rozmaite sfery i płaszczyzny rzeczywistości społecznej, zarówno w skali mikro-, jak i makrospołecznej. „Tworzą one podstawowy wzór - każdego życia" (Castells 2013, s. 33). W konsekwencji sieci powiązań stają się również istotnym elementem kształtowania współpracy transgranicznej, a tym samym kluczowym przedmiotem badań naukowych. Przykładem aplikacji perspektywy sieciowej na grunt badań nad granicami oraz pograniczami jest monografia naukowa „Sieci współpracy transgranicznej na pograniczach Polski”, której Autorką jest dr Sylwia Dołzbłasz, pracownik Instytutu Geografii i Rozwoju Regionalnego Uniwersytetu Wrocławskiego.

Książka jest bogatym studium teoretyczno-empirycznym, którego przedmiotem badań jest „(...) identyfikacja najważniejszych cech współpracy transgranicznej na poziomie lokalnym w ujęciu sieciowym oraz analiza zróżnicowania współpracy w Polsce (...)" (Dołzbłasz 2017, s. 11). Na potrzeby badań Autorka dokonała analizy bilateralnych działań $\mathrm{w}$ ramach programów współpracy transgranicznej, współfinansowanych ze środków unijnych i realizowanych na obszarach przygranicznych Polski. Punktem wyjścia do przeprowadzenia analizy sieciowej było określenie tematycznego zakresu współpracy oraz stopnia zaangażowania poszczególnych instytucji we

Address for correspondence/ Adres korespondencyjny: dr Dawid Błaszczak, Państwowa Szkoła Wyższa im. Papieża Jana Pawła II w Białej Podlaskiej, Wydział Nauk o Zdrowiu i Nauk Społecznych, Zakład Socjologii, ul. Sidorska 95/97, 21-500 Biała Podlaska, Polska; tel. +48 83 344 99 11; e-mail: dawidblaszczak@wp.pl, ORCID 0000-0001-7335-8343.

Journal indexed in/ Czasopismo indeksowane w: AgEcon Search, AGRO, BazEkon, Index Copernicus Journal Master List, ICV 2016: 92,91; Polish Ministry of Science and Higher Education 2016: 9 points/ AgEcon Search, AGRO, BazEkon, Index Copernicus Journal Master List ICV 2016: 92.91; Ministerstwie Nauki i Szkolnictwa Wyższego 2016: 9 punktów. Copyright: (c) 2017 Pope John Paul II State School of Higher Education in Biała Podlaska, Dawid Błaszczak. All articles are distributed under the terms of the Creative Commons Attribution-NonCommercial-ShareAlike 4.0 International (CC BY-NC-SA 4.0) License (http://creativecommons.org/licenses/by-nc-sa/4.0/), allowing third parties to copy and redistribute the material in any medium or format and to remix, transform, and build upon the material, provided the original work is properly cited and states its license. 
structure and dynamics was possible due to the analysis of all projects with the emphasis on the size and type of projects and characteristics of the beneficiaries of the programs. As a result, the study included 890 projects approved for implementation from 2007 to 2013, and 716 projects implemented from 2004 to 2006. 2508 and 716 beneficiaries participated in the implementation of these projects, respectively.

The key element of the research carried out for the book reviewed was the analysis and subsequent identification of changes in the development of the cooperation network in Poland. The network analysis is complemented by a formal and institutional cooperation synthesis, concerning the type of institutions involved in the projects, their location and activity, measured by the number of the undertaken projects and the amount of co-financing of these activities.

In the course of implementing the empirical part, the author formulated seven hypotheses:

1. Cooperation networks on the Polish borderlands are not well developed, and their features include a small number of nodes (units) with a high degree of centrality, which could be the main links in the development of cooperation.

2. Beneficiaries carrying out the largest number of cross-border projects are at the same time key nodes of the cross-border cooperation network in the borderlands (determined on the basis of network measures).

3. The factor of distance from the border influences the shaping of cooperation structures; the proximity of the border influences greater activity of subjects within cross-border cooperation and influences their role in the cross-border cooperation network.

4. The level of development of network connections and the nature of cooperation depends on the type of border and border features.

5. The similarity of partners favours establishing cooperation - dominating are cooperation projects implemented by partners of the same type. The result is a high level of homophily in the cooperation network.

6. There is a thematic concentration of projects and a generic concentration of cooperation programs beneficiaries. At the same time, there is a lack of spatial concentration of projects and beneficiaries.

7. In subsequent periods of implementation of cross-border cooperation programs (2004-2006 and 2007-2013), one can observe changes in the thematic structure of the undertaken projects, but at the same time, it is accompanied by the repeatability of beneficiary structures.

The hypotheses presented are closely related to both the main objective of the study and the four specific objectives of empirical and cognitive nature. It should be noted that the objectives have been formulated clearly, and the research methodology is presented in a transparent, detailed and comprehensive manner, as evidenced by both współpracę. Określenie i wizualizacja jej struktury i dynamiki możliwe było dzięki analizie wszystkich projektów z położeniem nacisku wielkość i rodzaj projektów oraz charakterystykę beneficjentów programów. W efekcie w badaniach uwzględnionych zostało 890 projektów zatwierdzonych do realizacji w okresie 2007-2013 oraz 716, realizowanych w latach 2004-2006. W realizacji tych projektów wzięło udział odpowiednio 2508 i 716 beneficjentów.

Kluczowym elementem badań, przeprowadzonych na potrzeby recenzowanej książki, była analiza, a następnie identyfikacja zmian w kształtowaniu się sieci współpracy w Polsce. Analizę sieciową uzupełnia formalno-instytucjonalna synteza współpracy, dotycząca rodzaju instytucji zaangażowanych w projekty, ich lokalizacji oraz aktywności, mierzonej liczbą podjętych oraz kwotą dofinansowania tych działań.

W toku realizacji części empirycznej autorka sformułowała siedem hipotez:

1. Sieci współpracy na pograniczach Polski są słabo rozwinięte, a ich cechą jest mała liczba węzłów (jednostek) o wysokim stopniu centralności, które mogłyby stanowić główne ogniwa rozwoju współpracy.

2. Beneficjenci realizujący największą liczbę projektów transgranicznych stanowią równocześnie kluczowe węzły sieci współpracy transgranicznej na pograniczach (określone na podstawie miar sieciowych).

3. Czynnik odległości od granicy ma wpływ na kształtowanie struktur współpracy; bliskość granicy wpływa na większą aktywność podmiotów we współpracy transgranicznej i ma wpływ na ich rolę w sieci współpracy transgranicznej.

4. Poziom rozwoju powiązań sieciowych oraz charakter współpracy jest warunkowany w zależności od rodzaju granicy i cech pogranicza.

5. Podobieństwo partnerów sprzyja nawiązywaniu współpracy - dominują projekty współpracy realizowane przez partnerów o tym samym rodzaju. Efektem tego jest wysoki poziom homofilii sieci współpracy.

6. Występuje koncentracja tematyczna projektów oraz koncentracja rodzajowa beneficjentów programów współpracy. Jednocześnie towarzyszy temu brak koncentracji przestrzennej projektów i beneficjentów.

7. W kolejnych okresach realizacji programów współpracy transgranicznej (2004-2006 oraz 2007-2013) obserwować można zmiany w strukturze tematycznej podejmowanych przedsięwzięć, ale jednocześnie towarzyszy temu powtarzalność struktur beneficjentów.

Prezentowane hipotezy mają ścisły związek zarówno $\mathrm{z}$ głównym celem opracowania, jak również z czterema celami szczegółowymi, mającymi charakter empiryczny i poznawczy. Należy przy tym zaznaczyć, że cele zostały jasno sformułowane, zaś metodologia badań ujęta w sposób przejrzysty, szczegółowy i wyczerpujący, o czym świadczą zarówno rozdziały teoretyczne, jak również empiryczne. Konstrukcja oraz zakres tematyczny monografii zostały precyzyjnie podporządkowane realizacji przyjętych 
theoretical and empirical chapters. The design and thematic scope of the monograph were precisely subordinated to the implementation of the objectives and verification of research hypotheses. The strength of the publication reviewed is the procedure related to the research procedure, which consists of the analysis of the thematic structure of projects and the structure of beneficiaries and institutions, spatial distribution analysis and network analysis by means of the Ucinet and NetDraw programs. In the conducted analysis, the author takes into account the basic parameters describing the properties of network structures, such as: network density, number of nodes, number of components, node degree, its proximity and transience.

The research conducted by the author is interesting and very important from the theoretical and applicational point of view. The monograph by $\mathrm{Dr}$. Sylwia Dołzbłasz is a rich study of knowledge in the field of cross-border cooperation and development of border areas, often considered peripheral. The study is on the one hand a supplement to previous research, conducted at least since the 1990s, on the other, due to the use of the network approach, it is characterized by a multi-faceted and innovative approach to the issues.

Dr. Sylwia Dołzłasz's scientific monograph is composed of four chapters, the first of which is a synthetic approach to goals and hypotheses, followed by the content concerning applied research approach as well as the spatial and temporal scope of the research. In the second chapter, the author discusses the issue of border research, including changes referring to concepts, topics and research approaches concerning the border and borderlands (phenomena and processes such as: debordering, borderless world, rebordering, border territoriality, etc.). The author also makes a synthetic and wide presentation of interdisciplinary approaches and research problems by E. Brunet-Jailly, D. Newman, G. Popescu, A. Passi and M. Perkmann. The third chapter is dedicated to the institutional and non-institutional determinants of cross-border cooperation (including the European Territorial Cooperation program) and the dynamics of transformations and development of cross-border cooperation in Poland and Europe. In the fourth chapter, the author conducts an empirical analysis of the cross-border cooperation network on individual Polish borderlands, adequately to the distribution and nature of European programs from which activities are co-financed. The chapters are complemented by a substantive summary and conclusions, as well as a comprehensive list of national and foreign literature on the subject, documents and legal acts. The content of the work also includes 88 figures, 21 tables and 8 attachments, which include classification tables and design maps, which are own studies of dr. Sylwia Dołzbłasz. The author devotes a lot of space in her work to the network analysis application for research on the border and borderlands. It is worth to emphasize that in the case of analysis of structures, processes and phenomena on the borderland, it is a relatively young celów i weryfikacji hipotez badawczych. Mocną stroną recenzowanej publikacji jest procedura związana z postępowaniem badawczym, na którą składają się: analizy struktury tematycznej projektów oraz struktury beneficjentów i instytucji, analiza rozkładu przestrzennego oraz analiza sieciowa za pomocą programów Ucinet i NetDraw. W przeprowadzonej analizie Autorka uwzględnia podstawowe parametry opisujące właściwości struktur sieciowych, takie jak: gęstość sieci, liczba węzłów, liczba komponentów, stopień węzła, jego bliskość i przejściowość.

Podejmowana przez Autorkę problematyka badawcza jest interesująca i bardzo istotna z punktu widzenia teoretycznego i aplikacyjnego. Monografia dr Sylwii Dołzbłasz jest bogatym studium wiedzy z zakresu współpracy transgranicznej oraz rozwoju obszarów przygranicznych, niejednokrotnie uważanych za peryferyjne. Opracowanie z jednej strony jest uzupełnieniem dotychczasowych badań, prowadzonych co najmniej od lat 90 -tych, z drugiej, z racji zastosowania podejścia sieciowego odznacza się wieloaspektowym i nowatorskim ujęciem problematyki.

Monografia naukowa dr Sylwii Dołzbłasz złożona jest z czterech rozdziałów, z których pierwszy jest syntetycznym ujęciem celów i hipotez, w dalszej kolejności zawiera treści dotyczące zastosowanego podejścia badawczego, jak również zakresu przestrzennego i czasowego badań. W rozdziale drugim Autorka podejmuje rozważania nad problematyką badań nad granicami, w tym nad zmianami odnoszącymi się do pojęć, tematyki i podejść badawczych dotyczących granicy i pograniczy (zjawiska i procesy takie jak: debordering, borderless world, rebordering, border territoriality, itd.). Autorka dokonuje przy tym syntetycznej i szerokiej prezentacji interdyscyplinarnych podejść i problemów badawczych autorstwa m.in.: E. Brunet-Jailly, D. Newmana, G. Popescu, A. Passi, M. Perkmanna. Rozdział trzeci poświęcony jest instytucjonalnym i pozainstytucjonalnym uwarunkowaniom współpracy transgranicznej (m.in. programowi Europejskiej Współpracy Terytorialnej) oraz dynamice przeobrażeń i rozwoju współpracy transgranicznej w Polsce i Europie. W rozdziale czwartym Autorka przeprowadza empiryczną analizę sieci współpracy transgranicznej na poszczególnych pograniczach Polski, adekwatnie do rozkładu i charakteru programów europejskich, z jakich współfinansowane są działania. Dopełnieniem rozdziałów jest merytoryczne podsumowanie i wnioski oraz bogaty spis krajowej i zagranicznej literatury przedmiotu, dokumentów i aktów prawnych. Zawartość pracy stanowi również 88 rycin, 21 tabel i 8 załączników, na które składają się tabele klasyfikacyjne i mapy projektowe, będące opracowaniami własnymi dr Sylwii Dołzbłasz. Wiele miejsca w swojej pracy Autorka poświęca aplikacji analizy sieciowej do badań granic oraz pograniczy. Warto podkreślić, że w przypadku analizy struktur, procesów i zjawisk na pograniczach jest to stosunkowo młode, ale rozwijające się podejście empiryczne, od wielu lat z powodzeniem stosowane $w$ innych naukach, zarówno społecznych, jak również ścisłych. Autorka dużo uwagi poświęca zagadnieniom związanym ze zmianą podejść badawczych i założeń teore- 
but developing empirical approach, successfully used for many years in other area of science, both social and natural science. The author pays a lot of attention to issues related to the change of research approaches and theoretical assumptions in the study of borders and borderlands. This is suggested, inter alia, by the title of one of the chapters, in which dr. Sylwia Dołzbłasz writes about the transition from the line to the network.

The strength of the monograph is the author's use of a broad spectrum of the existing literature on the subject. Dr. Sylwia Dołzbłasz successfully applies network theories to her own research, while showing exemplary knowledge of this type of research approach. Undoubtedly, the indisputable asset of the monograph is a comprehensive, theoretical and empirical approach to the problem of, firstly, the importance of European projects in the development of border areas; secondly, the advantages of building a network of relations and connections in the border areas; thirdly, the values related to the application of the network approach to grasp and describe the dynamics of processes and phenomena on the borderlands. The author is aware of the opulent values and wide practical application of the monograph, but clearly states that "The work aimed at indicating general regularities in the development of cooperation (...) on the borderlands of Poland and explaining phenomena accompanying the development of crossborder cooperation network taking into account all hypotheses and goals" (Dołzbłasz 2017, p. 21).

In the summary, dr. Sylwia Dołzbłasz presents the most important regularities characteristic for the shape of the analysed cooperation networks. She included, inter alia: the dominance of local government institutions at the local level, strong importance of government institutions (Belarusian side) and non-governmental institutions (Ukrainian side), participation of these institutions in several projects, relationship between the institution's location (near/far from the border) and the intensity of participation in the projects (except for the external EU border, which did not affect the intensity of participation in project initiatives). The quintessence of the summary is the author's statement that "The results of the analysis in dynamic terms indicates the occurrence of both certain changes and permanent trends in the formation of cross-border cooperation under programs co-financed by EU" (Dołzbłasz 2017, p. 243). In this case, the second part of the sentence can be treated as an incentive to undertake further research and analysis.

To summarize, let me point out that the scientific monograph by dr. Sylwia Dołzbłasz is a very valuable study, as evidenced by editorial values, vast erudition, innovative empirical approach and reaching for the national and foreign literature of the subject. The author expands, systematizes and organizes knowledge about the cooperation networks on the borderlands, setting a vector for future research and analysis, for which one should undoubtedly reach and which one should continue. tycznych do badania granic i pograniczy. Sugeruje to między innymi tytuł jednego z rozdziałów, w którym dr Sylwia Dołzbłasz pisze o przejściu od linii do sieci.

Mocną stroną monografii jest wykorzystanie przez Autorkę szerokiego spektrum dotychczasowej literatury przedmiotu. Dr Sylwia Dołzbłasz skutecznie aplikuje teorie sieciowe na grunt badań własnych, wykazując się przy tym wzorową znajomością tego typu podejścia badawczego. Niewątpliwie bezdyskusyjnym walorem monografii jest całościowe, teoretyczne oraz empiryczne ujęcie problematyki, odnoszącej się po pierwsze, do znaczenie projektów europejskich w rozwoju obszarów przygranicznych; po drugie, walorów budowania sieci relacji i powiązań na obszarach przygranicznych; po trzecie, walorów związanych z zastosowaniem podejścia sieciowego do uchwycenia i opisu dynamiki procesów i zjawisk na pograniczach. Autorka ma świadomość bogatych walorów i szerokiego zastosowania praktycznego monografii, wyraźnie zaznacza, jednak, że „Praca miała na celu wskazanie generalnych prawidłowości w rozwoju współpracy (...) na pograniczach Polski oraz wyjaśnienie zjawisk towarzyszących kształtowaniu się sieci współpracy transgranicznej uwzględniających wszystkie hipotezy oraz cele" (Dołzbłasz 2017, s. 21).

W skład części podsumowującej dr Sylwia Dołzbłasz prezentuje najważniejsze prawidłowości, charakterystyczne dla kształtu analizowanych sieci współpracy. Zalicza do nich między innymi: dominację instytucji samorządu terytorialnego na szczeblu lokalnym, silne znaczenie instytucji rządowych (strona białoruska) i pozarządowych (strona ukraińska), udział tych samych instytucji w kilku projektach, zależność między położeniem instytucji (blisko/daleko granicy) a intensywnością udziału w projektach (za wyjątkiem zewnętrznej granicy UE, która nie rzutowała na intensywność partycypacji w inicjatywach projektowych). Swego rodzaju clow podsumowania stanowi stwierdzenie Autorki, że „Wyniki analizy $\mathrm{w}$ ujęciu dynamicznym wskazują na występowanie zarówno pewnych zmian, jak i stałych tendencji w kształtowaniu się współpracy transgranicznej w ramach programów współfinansowanych z UE" (Dołzbłasz 2017, s. 243). W tym przypadku drugą część zdania możemy traktować jako zachętę do podjęcia dalszych badań i analiz.

Podsumowując pozwolę sobie zaznaczyć, że monografia naukowa dr Sylwii Dołzbłasz jest bardzo cennym opracowaniem, o czym świadczą walory edytorskie, bogata erudycja, nowatorskie podejście empiryczne czy sięgniecie po krajową i zagraniczną literaturę przedmiotu. Autorka poszerza, systematyzuje oraz porządkuje wiedzę na temat sieci współpracy na pograniczach, wyznaczając wektor przyszłych badań i analiz, do których niewątpliwie należy sięgać i kontynuować. 